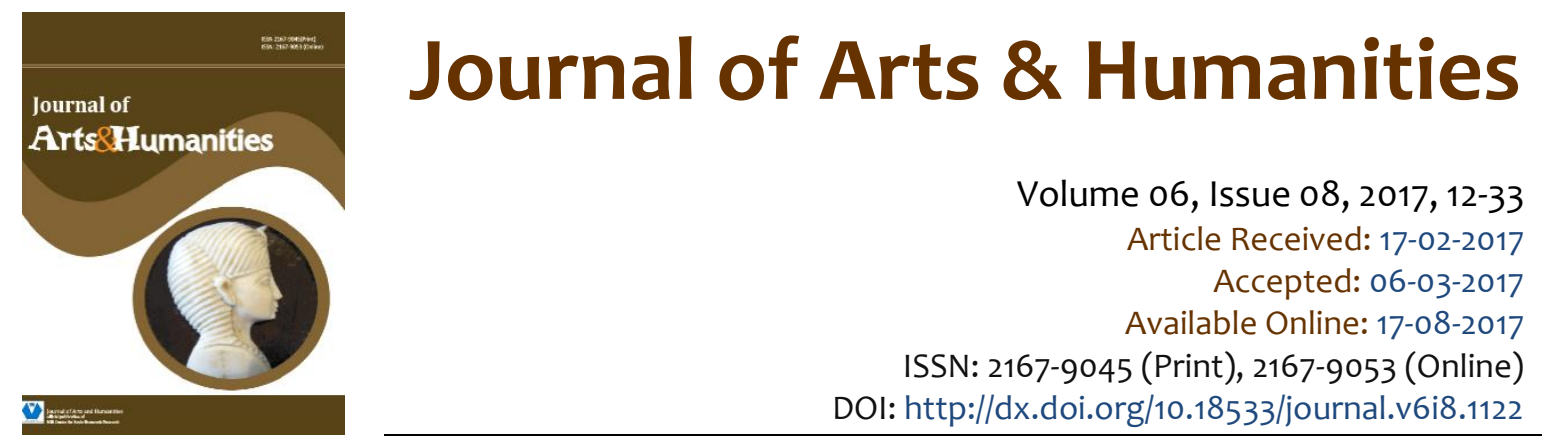

\title{
Public Health: Socio-Political History of a People
}

\author{
Samuel Adu-Gyamfi', Aminu Dramani², Kwasi AMakye-Boateng², Sampson Akomeah³
}

\begin{abstract}
This study focuses on the transformations that have characterised public health in Asante. The study highlights the changes that have occurred in the traditional public health which include the use of roots, leaves, back of trees and spiritualities' as well as the colonial administration's introduction of modern or western medicine and post-colonial inheritance. The domination of Asante from 19021957 by the British influenced the public health in Asante. This necessitated the introduction of western medicine, which included the building of hospitals and clinics and training of physicians to cater for the sick. Post-colonial Ghana after 1957saw a new direction in public health in Asante it ensured continuity and change. However, of the all the successes of traditional medicine and its importance even in modern times, an in-depth study of this subject has not received attention for the benefit of academia and society. It is critical to turn back, consider how public health was ensured in the first half of the twentieth century and balance it with modern practices. This will help us draw necessary lessons for modern society. This study, therefore, does a retrospective analyses/narrative on the accessibility and equitability of health to all citizens of Ghana and Asante in particular within the twentieth century and to further access the continuity and change over time.
\end{abstract}

Keywords: Asante, Ghana, Institutions, Modern/Western/Orthodox Medicine, Public Health, Regulations. This is an open access article under Creative Commons Attribution 4.0 License.

1. Introduction

From the normal human interactions involved in dealing with the many problems of social life, there has emerged recognition of the importance of community action in the promotion of health and the prevention and treatment of diseases; this is expressed in the concept of public health. From the earliest time, man has faced the challenge of meeting his health needs. According to Cambridge Advanced Learners dictionary, health refers "to the condition of the body and the degree to which it is free from illness or the state of being well". ${ }^{4}$ In the field of science, Stedman's Medical Dictionary

\footnotetext{
${ }^{1}$ Department of History and Political Studies, Kwame Nkrumah University of Science and Technology, Kumasi-Ghana. E-mail: mcgyamfi@yaho.com

2 Department of History and Political Studies, Kwame Nkrumah University of Science and Technology, Kumasi-Ghana

3 Ghana Education Service

4 Patrick Gillard, Cambridge Advanced Learners Dictionary, a definition of health, Cambridge university press, third edition, (2008).
} 
defines health as "the state of the organism when it functions optimally without evidence of diseases or abnormality". ${ }^{5}$ The constitution of the World Health Organization (WHO), also defines health as "the state of physical, mental, emotional and social wellbeing and not merely the absence of disease or infirmity. ${ }^{6}$ To consolidate the definition for health, how did other scholarly sources defined public health?

Macmillan English dictionary defines health as "the condition of your body, especially whether or not you are ill or the condition of being strong and well". 7 In this vein, the Encyclopedia Britannica defines Public health as "the art and science of preventing diseases, prolonging life, and promoting physical and mental health, sanitation, personal hygiene, control of infections and organization of health service". ${ }^{8}$ According to the World Health Organization (WHO), Public Health refers also "to all organized measures whether public or private to prevent disease, promote and prolong life among the population as a whole". ${ }^{9}$ World Health Organization (WHO) has maintained close relationships with the United Nations agencies, particularly the United Nations Children Fund and the Food and Agriculture Organization (FAO) concerning public health issues in the world. From the inception of UNICEF in 1946, it has focused on the aid of maternal and child health services and the control of infections, especially in children. ${ }^{10}$

Most of the world's primitive people have practiced cleanliness and personal hygiene, often for religious reasons, including apparently, a wish to be pure in the eyes of their gods. In the Bible, the Old Testament, for example, has many adjurations and prohibitions about clean and unclean living. For instance Leviticus 15 vs. 7 says, "The Lord said to Moses and Aaron," speak to the Israelites and say to them, when any man has a bodily discharge, the discharge is unclean". ${ }^{11}$ According to constable notes on Leviticus, this discharge could include vomit, faeces, menstruation, sweat among others which could be a threat to public health due to the spread of contagious diseases. ${ }^{12}$ For thousands of years, primitive societies looked upon epidemic as divine judgments as a result of the wickedness of mankind.

The idea that pestilence is due to natural causes, such as climate and physical environment, however, gradually developed. This great advance in thought took place in Greece during the fifth and fourth centuries BC. The first person to have considered Public Health in his writings was Hippocrates in his book "Airs", "Waters", and a "Places" in the fifth and fourth centuries BC respectively. ${ }^{13}$ Among the early pioneers in public health was John Graunt who in 1662 published a book of statistics, which had been compiled by parish and municipal councils of Italy that gave numbers for deaths and suggested their causes..$^{14}$ In 1852, Sir John Pringle published a book that discussed ventilation in barracks and the provision of latrines. ${ }^{15}$ Two years he had written about jail fever (now thought to be typhus) and again he emphasized the same needs as well as personal hygiene. ${ }^{16}$ In 1848 , the public health act was established and the general board of health came to furnish guidance and aid in sanitary matters to local authorities, whose earlier efforts had been impeded by lack of a central authority and idea were masterminded by Edwin Chadwick (Britain's premier pioneer in public health). ${ }^{17}$

Public health in Africa focuses on the health of the seven hundred and thirty-eight (738) million people living in the African region; according to World Health Organization (WHO) acknowledged that

\footnotetext{
5 The Williams and Wilkins company, Stedman's Medical Dictionary, A definition of health, Waverly Press, Inc. Baltimore, Md, twentieth edition, (1961).

${ }^{6}$ World Health Organisation, definition of health, (1946), $5^{\text {th }}$ October 2015.

${ }^{7}$ Macmillan English Dictionary, a definition of public health, Holtzbrinck Publishing Group and BC Partners. Second edition.

${ }^{8}$ World Health Organization, a definition of public health, (1946). www.WHO constitution.com. $5^{\text {th }}$ October, 2015.

9lbid.

${ }^{10}$ lbid.

${ }^{11}$ New International Standard Bible Version, Leviticus 15:7.

12 Thomas L. Constable notes on Leviticus $15: 7$ and Family Bible note commentary, 2015 edition, www.soniclight.com. 20 ${ }^{\text {th }}$ October, 2015.

"13Adam, Francis." The Genuine Works of Hippocrates", William Wood and Company, New York, (1891).

${ }^{14}$ Helen, M. Walker," Contributions of Karl Pearson". Journal of the America Statistical Association, volume. 53, No. 281 (March 1958) 2282561, www.jstor.org. $25^{\text {th }}$ October, 2015.

${ }^{15}$ Sir John Pringle, "Observations on the diseases of the Army: an early science of epidemiology and the prevention of cross infection". Journal of Epidemiology and Community Health, Volume 59, Issue 11 (1752), www. Jech.bmj.com. $28^{\text {th }}$ October, 2015. ${ }^{16} \mathrm{Ibid}$

${ }^{17 E d w i n ~ C h a d w i c k . ~ " T h e ~ H e a l t h ~ o f ~ N a t i o n s . ~ E x t r a c t ~ f r o m ~ t h e ~ R e p o r t ~ o f ~ t h e ~ P o o r ~ L a w ~ C o m m i s s i o n e r s ~ o n ~ a n ~ I n q u i r y ~ i n t o ~ t h e ~}$ Sanitary Conditions of the Labouring Population of Great Britain", London, (1842), pp.369-372.
} 
African confront the world's most dramatic public health crisis over the period of time. It is estimated that more than ninety percent (90\%) that is, three hundred (300) to five hundred (500) million malaria cases that occurred worldwide every year are among Africans, mainly in children under five years of age. But most countries are moving towards better treatment policies. River blindness has been eliminated as a public health problem, and guinea worm control efforts have resulted in a ninety-seven percent (97\%) reduction in cases since 1986. Then there is the strain on African health systems imposed by the high burden of life-threatening communicable diseases coupled with increasing rates of noncommunicable diseases such as hypertension and coronary heart disease. Basic sanitation needs remain unmet for many that are to say; only fifty-eight percent (58\%) of people living in sub-Saharan African have access to safe water supplies. Non-communicable diseases such as hypertension, heart disease, diabetes are on the rise and injuries remain among the top causes of death in the region. In this regard Africa cannot move forward with this fragile health system. ${ }^{18}$ African public health focuses on the traditional discipline of public health, including hygiene, epidemiology, health education, environmental health, occupational health, health policy, hospital management, health economics, laws and ethics as well as from the area of new health care fields including social science, communication science health philosophy, health technology assessment, population mental health gender and disparity issues, global and migration-related themes. ${ }^{19}$

In the sixteenth century, traditionally, village healers and clerics were the primary caregivers, offering herbal remedies. Though herbalists have traditionally offered the readiest treatment of elders, pre-modern traditional beliefs stressed the combination of spiritual healing. In the pre-colonial period, when the responsibility of the healthcare interest groups was for maintaining the social, economic and spiritual wellbeing of the society, the definition of illness and cure as the wrath of the gods and actions of mystical spirits served the interest of the coalition. This is because it enabled them to control the moral lives of the people and also gain their allegiance. ${ }^{20}$ Christian missionaries to the Gold Coast introduced the western public health in the nineteenth century. This religion was involved in the development of a new health care system. A pre-public health department was formed initially, and in 1878 the towns, Police and public health ordinance was enforced under it direction, initiating the construction and demolishing of infrastructure, draining of the street, and issuing fines to those that fail to comply with the head of the colony. In 1893, public works department was introduced to implement a working sanitation system for the colony. In the $1880 \mathrm{~s}$, the medical department was formed bringing about an introduction to a formal medical system, consisting of a laboratory branch for a research a medical branch of hospital and clinics and the sanitary branch for public health. ${ }^{21}$ The health of women in Ghana is critical for national development. The women health issues in the country are largely centered on nutrition, reproductive health and family planning. ${ }^{22}$ From the 1900 s the water supply and sanitation in Ghana has been gradually modernized through the creation of an autonomous regulatory agency, an introduction of private participation and decentralization of the rural supply to many areas, where user participation is encouraged. The reforms aimed at increasing cost recovery and modernization of urban utility. The reforms led to the establishment of Ghana Water Company, as well as rural water supply system to improve water problems in Ghana. ${ }^{23}$

In Ghana public health is grouped under two departments namely: disease surveillance department and disease control department. Both the diseases control and the surveillance are responsible for three distinct functions of the division, that is, the development and implementation of surveillance and disease control system for both communicable and non-communicable diseases consistent with national bilateral and international expectation. ${ }^{24}$ The provision of support monitoring

\footnotetext{
${ }^{18}$ World Health Organization, “African Regional Health Report... The health of the people" October 2015.

${ }^{19}$ Gelatti Umberto. "Department of Medical and Surgical Specialties, Radiological Science and Public Health" Journal of Public Health Research, Volume 4, No 2 (2015).

20 Edward Brenya, Samuel Adu-Gyamfi," Interest Groups, Issue Definition and the Politics of Healthcare in Ghana", Public Policy and Administration Research, Vol.4, No.6, (2225-0972), 2014, www.iiste.org. $12^{\text {th }}$ November, 2015.

${ }^{21}$ Samuel Adu- Gyamfi, Prince, O.W. Adjei, Daniel Owusu- Ansah," Preventive healthcare strategies and impact among the Asante people of the early twentieth century Gold Coast: A historical narrative and lessons for thepresent sanitation challenges in Kumasi”. Journal of studies in social sciences, Volume 5, No.2, (2013), www.infinitypress.info. $15^{\text {th }}$ November, 2015. ${ }^{22}$ Ghana Demographic and Health Survey Report. (2008). www.dhsprogram.com. $15^{\text {th }}$ October, 2015.

23Water Aid. "National Water Sector Assessment in Ghana" (2008). Www.wateraid.org. 15 $5^{\text {th }}$ November, 2015.

${ }^{24}$ Powered by Ghana Health Service ICT Department (2014). www.ghanahealthservice.org. 16 $6^{\text {th }}$ November 2015.
} 
and evaluation of disease control programs and projects in collaboration with the region, districts and other health programs implementing agencies with the view to promoting program effectiveness and efficiency as well as the view of public health intervention, financing and resource (human and infrastructure) allocation strategies and its impact and access, including quality and efficiency to the people of Ghana. ${ }^{25}$ Oral traditions have shown that the people of Asante as a whole faced the challenge of providing health care from very earlier times. In fact, all humans have in one way or the other shown resilience in fighting anything that has the potential of threatening their existence including diseases. ${ }^{26}$

The people of Asante have faced several problems concerning the provision of health care from earliest times. Kumase is the current administrative capital of Asante, it is centrally located in Ghana and its peopling is known in a collective term as "Asantefo". Their official language is Asante. Among the Asante traditional health, illness is seen as a deviant behaviour. Illness is a disturbance in the normal functioning of the human being at the biological and social levels. Asante believed that the basis is that illness is not a normal condition but something that disturbed or interrupted the arrangement of social relationship and productivity. Public health practices in Asante traditional societies were closely linked to religion because religion covers every facet of life. ${ }^{27}$ Needless to say, none of the basic needs just identified can be achieved and enjoyed without good health. Good health is thus the main prerequisite for all human activities. In other words, political activities, religiosity, economic activities, family obligations and educational activities would be seriously disrupted without good health being available to the people of Asante. Adu- Gyamfi refers to Twumasi that:

The characteristics of the sick role in the society are that in so far as he is legitimately recognized as a sick person, he is temporarily relieved of his obligations of his work activities. If he is a father he is not obliged to attend work to support his family or take part in the decision-making process of his various social groups. This role is legitimated by the elders of the family and reinforced by the traditional medicine man when the case comes to his medicinal shrine. ${ }^{28}$

As a consequence, the public health was developed as a safeguard of the health needs of the society. ${ }^{29}$ The major public health tool that was used by the Asante before British control was communal labour. Asante's proverbs, myths, and taboos were used as a yardstick to promote public health. Asante has the notion that every social act (including the causation of disease and other ills) has a reference to the supernatural powers: that is to gods, the ancestors as well as to men. ${ }^{30}$ Asante's public health was basically governed by local authority.

From 1902, Britain had total control over the Asante territory and declared it a colony under the colonial Administration. Henceforth, the colonial Administration placed emphasis on Europeans public system. European public health was practiced in Asante in the period of colonial rule. Adu-Gyamfi (2010:103) maintain that:

The Colonial Administration attributed the belief in the wrath of deities, magic and mystical actions of demons such as witchcrafts as the cause of diseases to ignorance that creates fear in the people. The causes of diseases were attributed to biological and environmental factors, which beloved on the Colonial Administration to take over the management of healthcare. Therefore, the provision and finance of health care became a responsibility of the Colonial government who ordered all cases of contagious diseases to be reported to government doctors to treat them scientifically. ${ }^{31}$

The general importance of public health is not only in ensuring that healthy people exist to work for their own betterment but also to ensure that there is a healthy society to live in; this is

\footnotetext{
${ }^{25} \mathrm{Ibid}$

${ }^{26}$ Samuel, Adu-Gyamfi and Wilhelmina J. Donkor "Historical Review of Diseases and Diseases Prevention of Gold Coast" focus on Asante (1900-1957)", Historical Research Letter, volume 5, 2013, The International Institute for Science, Technology, and Education. www.iistr.org. $17^{\text {th }}$ November, 2015.

${ }_{27}^{27 . K . ~ N u k u n y a, ~ " T r a d i t i o n ~ a n d ~ C h a n g e ~ i n ~ G h a n a: ~ A n ~ I n t r o d u c t i o n ~ t o ~ S o c i o l o g y " . ~ G h a n a ~ U n i v e r s i t y ~ P r e s s, ~ A c c r a, ~(2003) . ~}$

28 Samuel Adu- Gyamfi, Prince, O.W. Adjei, Daniel Owusu- Ansah," Preventive healthcare strategies and impact among the Asante people of the early twentieth century Gold Coast: A historical narrative and lessons for the present sanitation challenges in Kumasi", Journal of studies in social sciences, Volume 5, No.2, (214238). 2013, www.infinitypress.info. $15^{\text {th }}$ November, 2015.

29ibid

30Peter Sarpong," Ghana in Retrospect: Some Aspects of Ghana Culture”, Ghana Publishing Corporation, Tema, 1974.

${ }^{31}$ Samuel, A. Gyamfi. "A Historical Study of the Impact of Colonial Rule on Indigenous Medical Practices in Asante: A Focus on Colonial and Indigenous Disease Combat and Prevention Strategies in Kumase 1902-1957". PhD Thesis, KNUST 2010.
} 
something that cannot be underestimated. Also, the high level of seriousness placed on health education by international organizations such as the World Health Organization (WHO) and the United Nations (UN) goes a long way to buttress the outstanding reality that public health is a very important issue to deal with. It is therefore against this background that it becomes highly imperative to do a pragmatic and thorough research on public health in Asante.

Prior to the arrival of the British, the traditional Asante society treated diseases through methods involving magic, healers, and animal sacrifices. Public health was decentralized and administered by local authorities to check and enforce laws, taboos and other social mechanisms used to control and prevent epidemics in Asante. ${ }^{32}$ These mechanisms helped to promote the sanitation situation in Asante and as a result reduced tropical diseases like malaria and yellow fever before 1902, which did not necessarily come about as a result of poor sanitation. ${ }^{33}$

Among most of the colonies in the Gold Coast, public health in Asante seemed to be regarded as the most important in the colonial Administration. However, the Asante faced some worst form of public health conditions in the colony in the sense that most of the public health institutions were reserved for Europeans. Significantly, the period 1902 to 1930 was noted to have had widespread epidemics and the general health of the local people of the Gold Coast and specifically that of Asante was unsatisfactory. ${ }^{34}$ Notable among this was the government's inability to combat contagious diseases such as cholera in Asante. The problems created by the colonial administration were the isolation of hospitals, poor disinfection procedure, and inadequate disposal of sewage, food, and inadequate personnel for food inspection among others. ${ }^{35}$

The central issue is about the legitimacy of the colonial government. At one level it was the desire of the colonial government to be fully in charge of the public health problems in Asante, at another level, the colonial government wanted to use the local leaders to administer these public health policies. This politicization, in the form of manipulation of the indigenous public health, which began under colonial rule, continued after independence, which resulted in the escalation of poor sanitary conditions in modern Ghana.

The colonial public health evolved out of a need to establish proper sanitary and hygienic condition for the people of Asante as well as prevention of epidemics from the community. Its historical transformation, role, and image played by public health during the colonial and post-colonial period are interrelated. Celsus stated that a person should put aside some part of the day for the care of his body and should always make sure that he gets enough exercise, especially before a meal. In this regard, the Romans were great believers in a healthy mind equaling a healthy body and that illness is a natural cause and that bad health could be caused by bad water and sewage. ${ }^{36}$

Hence their desire to improve the public health system in the Romans Empire so that everyone in the empire benefited and public health programme was for everyone regardless of wealth. This made the Romans the first empire to reach civilization in public health. The impacts of Italian public health to the world as a whole is to monitor, review and systematize the policy implications of the social and economic determinants of population health for wider development of a global public health. ${ }^{37}$

From this view, it will be of immense value to a nation and scholars to study public health especially that of Asante, which has seen little or no systematic historical research.

The objective of this paper is four-fold. The main objective is to rehash the historical trend of Public Health in Ghana during the colonial and post-colonial period, focusing on Asante, from 1902 to 1966. The other objectives include: tracing the transformations and public health policies in British colonial Asante; to analyze the changes that the colonial administration instituted in public health in

\footnotetext{
32K Arhin," Traditional Rules in Ghana, past and present", 1985.

33 lbid

34 Samuel Adu- Gyamfi, Prince, O.W. Adjei, Daniel Owusu- Ansah," Preventive healthcare strategies and impact among the Asante people of the early twentieth century Gold Coast: A historical narrative and lessons for the present sanitation challenges in Kumasi", Journal of studies in social sciences, Volume 5, No.2, 2013.www.infinitypress.info. $15^{\text {th }}$ November, 2015 35Kojo Senah, In Sickness and in Health: "Globalization and Health Care Delivery in Ghana", reviewed, 2001.

${ }^{36}$ Aulus Cornelius Celsus," De Medicina", (First century AD, Rome)

37Suhrcke M, de Paz Nieves C. "The impact of health and health behaviours on high-income countries: a review of the evidence". WHO Regional Office for Europe, Copenhagen, 2011.
} 
Asante and finally to examine the impact of public health under the first Republic of Ghana (1960-1966) and Asante in particular.

\section{Research framework and methodology}

This paper is based on ideational knowledge systems, institutional and pragmatic approach. The work of Adu-Gyamfi (2010) refers to how ideational knowledge in the field of herbal and non-herbal medicaments as well as institutions as established by the British Colonial Administration and the traditional institutions in the Gold Coast and Asante engendered support for one another to proffer solutions to the health challenges that affected both European and Indigenous well-being. This theoretical construct amply applies in this study. In addition, charismatic and pragmatic leadership is found to be feasible in this paper. Charismatic leaders, in the formation of their prescriptive mental models, are held to stress goals - typically positive, future-oriented goals (Conger \& Kanungo, 1988). ${ }^{38}$ For pragmatic leaders, goals are given created by objective threats and opportunities evident in the situation at hand. As a consequence, the prescriptive mental models formulated by pragmatic leaders stress the causes giving rise to these threats and opportunities within the local situation (Mumford \& Van Doorn, 2001). ${ }^{39}$ You shall find from the narrative both human charismatic and pragmatic line of leadership as well as ideational basis of doing things that served as the undergirding for the public health policies that came on the back of traditions, colonialism and colonial institutions and postcolonial initiatives of leaders like Nkrumah.

Methodologically, the paper is based on ethnographic and inter-disciplinary approach using written, oral traditions and observations as sources of data. The researchers used the field interview technique to collect oral data. The written sources include primary sources and secondary sources. Some of the secondary sources used include information from books related to the history of Public health. Journal articles were also used in writing the research. The other sources of information were accessed from the internet. Information was also collected from archival sources. Similarities and contrasts in the various data collection tools used have been noted in this study.

The primary written sources were retrieved from the Public Records and Archives Administration (PRAAD), Kumase. Data like the memo between The Colonial Secretary of State, District Commissioners, Secretary for Native Affairs, Infectious Disease files among others were retrieved. ${ }^{40}$ The others include information relating to the correspondence between the Asantehene and Chief Commissioners, letters and minutes of colonial commissions and committees including those of the Kumase Public Health Board among others. In addition, annual reports from the Office of Public Health, rare books, and other relevant publications were used. Public Health Administrators have been interviewed to retrieve information for the writing of this paper. The standard for the selection of the interviewees was based on their specialization and experience in Asante, the research area.

\section{Postulations from related literature}

In their work, "Definition of Public Health: Historical and Contemporary Developments", Lioyd F. Novick and Cynthia B. Morrow (2011) asserted that the definition of public health must reflect its central goal - the reduction of disease and the improvement of health in a community". ${ }^{41}$ They therefore defined Public health as comprising organized efforts to improve the health of communities. They indicated thatpublic health prevention strategies are targeted to populations rather than individuals. They emphasized thatpublic health practice does not rely on a specific body of knowledge and expertise but rather relies on a combination of science and social approaches. ${ }^{42}$ They further stated that throughout history, public health efforts have been directed towards the control of transmissible

\footnotetext{
${ }^{8}$ Conger, J. A., \& Kanungo, R. S. (1988). Toward a behavioral theory of charismatic leadership in organizational settings. Academy of Management Review, 12, 637-647.; Conger, J. A., \& Kanungo, R. S. (1998). Charismatic leadership in organizations. Thousand Oaks, CA: Sage.

39 Mumford, M. D., \& Van Doorn, J. R. (2001). The leadership of pragmatism: Reconsidering Franklin in the age of charisma. Leadership Quarterly, 12, 274-309

${ }^{40}$ Samuel, A. Gyamfi. "A Historical Study of the Impact of Colonial Rule on Indigenous Medical Practices in Asante: A Focus on Colonial and Indigenous Disease Combat and Prevention Strategies in Kumase 1902-1957". PhD Thesis, KNUST (2010), page 21.

${ }^{41}$ Lioyd F. Novick and Cynthia B. Morrow, "Defining Public Health: Historical and Contemporary Developments, 2011 42 ibid
} 
diseases, reduction of environmental hazards and provision of safe drinking water. ${ }^{43}$ They pointed out that because social, environmental and biological factors interact to determine health, public health practice must utilize a broad set of skills and interventions. ${ }^{44}$

However, Winslow (1920) in his Study titled "The Untilled Fields of Public Health", provides the following definition of public health practice:

"public health is the science and art of preventing disease, prolonging life and prolonging physical health and efficiency through organized community efforts for the sanitation of the individual, the control of community infections, the education of the individual in principles of personal hygiene, the organization of medical and nursing services for the early diagnosis and preventive treatment of disease and development of social machinery which will ensure to every individual in the community a standard of living adequate for the maintenance of health. ${ }^{45}$

Contrasting Lioyed et al., (2011), Winslow have stated unequivocally that Public health differs from clinical medicine by emphasizing prevention and keying interventions to multiple social and environmental determinants of disease; clinical medicine focuses on the treatment of the individual. ${ }^{46}$ However interaction between public health and medicine is necessary because individual health and community health are elements of a continuum.

Kojo Senah (2001) asserted that essentially, the development of the colonial health service may be seen in three major phases. The first phase (1471-1844) was characterized by medical apartheid whereby white settlers were physically segregated from the local population and given medical coverage. ${ }^{47}$ Kojo Sena (2001), added that the policy has been to provide a European quarter in order that the risk of malaria infection from the insanitary conditions of native houses and from infected natives may be reduced. Kojo Senah (2001) went further to observe in his research report that Following the signing of the Bond of 1844 between the British and some local chiefs, relative peace was ensured in the colony and this enhanced European commercial and Christian missionary activities in the hinterland. It soon dawned on the Europeans that their health could no longer he guaranteed unless the health needs of the local population were also met. Thus, the second phase of the colonial health service was born when health coverage was extended to African domestic servants and those in the colonial civil and military service. ${ }^{48} \mathrm{He}$ further observed that towns with a sizeable European presence were provided with piped water, a drainage system, and other sanitary facilities (Senah, 1983, 1989 and 2001 revised). No wonder in 1868 the first hospital was built at Cape Coast (then the colonial capital) and subsequently rural dispensaries were built in several localities, Senah (2001) observed. ${ }^{49}$

Lioyed et al., (2011) commenting on the definition of Public Health, Historical and Contemporary Developments observed differently that during the $20^{\text {th }}$ century, the historic emphasis on protecting communities from infectious disease and environmental threats expanded to counter risks from behaviours and lifestyles that led to chronic disease. ${ }^{50}$ The two scholars rather asserted that population-based prevention resulted in major gains in the life expectancy during the $1900 \mathrm{~s} .{ }^{51} \mathrm{It}$ is clear from LioyedNovick and Cynthia B. Morrow (20110 that, in the beginning of the $20^{\text {th }}$ century, public health expanded even further as numerous events necessitated a shift in public health priorities. In almost a different way, in addressing issues in the Health Sector Reform and Deployment, Training and Motivation of Human Resources towards Equity in Health Care: Issues and Concerns in Chana", Delanyo Dovlo (2001), observed that by the mid1980s, like other sub-Saharan African countries, frequent coups d'état and changes in government and economic decline had contributed to severe reductions in the resources available for health care. This, according to Devlo (2001) resulted in poor service conditions for health workers and a rapid decline in morale. He added that Primary Health Care Policy and Strategy papers were produced in 1979. It is clear from Devlo (2001) that efforts towards improvement of Public

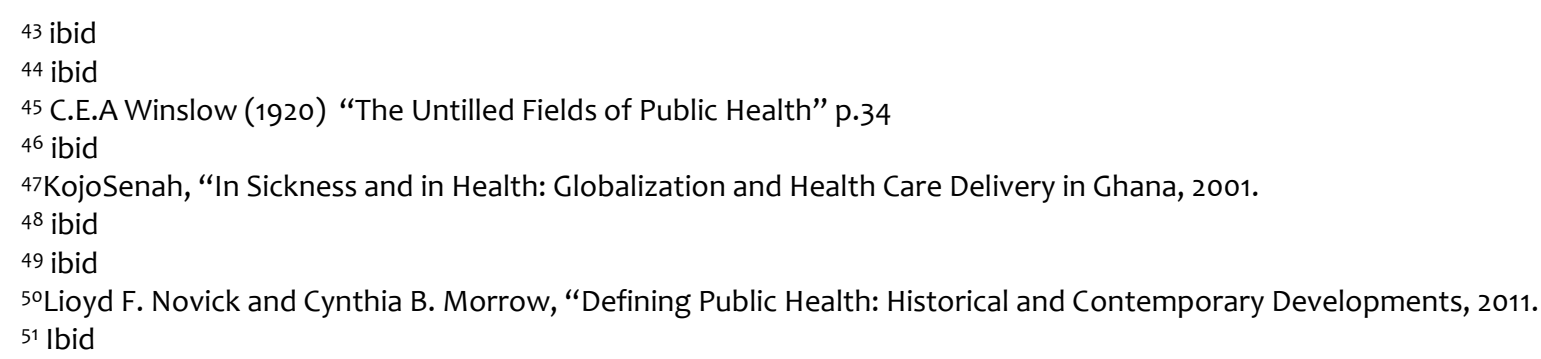


Health moved toward developing district health teams and district based health service systems in order to refocus priorities towards basic clinical and prevention oriented services. Devlo (2001) moved further to indicate that, in 1985, the government of Ghana introduced user fees into the health services marking a significant shift in health policy towards cost recovery, decentralization of management and rationalization of services. A report in a World Bank publication indicated an estimated fifty thousand $(50,000)$ surplus staff in the Ghana Public Sector. In the government health sector, it was estimated that out of a total of thirty-eight thousand $(38,000)$ staff in 1987 , some twenty-two thousand $(22,000)$ were non-technical or unskilled staff and eight thousand $(8,000)$ of these were redundant labour. ${ }^{52}$ From this, it is revealed that the number of mainly unskilled staff was redeployed with the aim of improving the proportion of trained health workers providing services when he pointed out that staffing levels in the health services were reduced from approximately thirty-eight thousand $(38,000)$ to twenty-seven thousand $(27,000)$ over a five year period. ${ }^{53}$

Devlo (2001), further pointed out that in terms of human resources, the health sector in Ghana was described as having inadequate numbers of rather poorly motivated staff, who were inequitably distributed both in terms of numbers as well as skills. The main human resource concerns according to Devlo (2001) are as follows: The actual numbers and the distribution of personnel,the skill mix that is available, including the issue of monopoly of skills by some professions through regulations and legislation; whether the skills were distributed in the same proportion as the population; remuneration, incentives and motivation and how this is reflected by work location and the relative "importance" or priority of the service provided, and Supply and requirement for various cadres and skills types. 54

Touching on the North/South Divide in Staff Distribution as well as the Rural/Urban Divide, Devlo (2001) narrates that the Northern sector of the country had more than two fifth ( $2 / 5$ )of the national land mass and thirty percent (30\%) of the population. However, it had only twenty percent $(20 \%)$ of the total health personal. In terms of the "quality" of staff, the three northern regions had six percent $(6 \%)$ of the doctors, or a total of sixty-four doctors for about four million people. Approximately thousand (1000) remaining doctors provided services for the twelve million people in southern Ghana. ${ }^{55}$ Fifty percent (50\%) of all doctors were based in the national capital area of Greater Accra Region (in both the Regional Level and in the National Teaching Hospital) which had approximately twelve point five percent (12.5\%) of the population. The district and sub-district levels were used as surrogates for the rural areas. The districts had restricted authority to manage their own affairs, including recruitment of even the lowest cadres of staff who were still centrally recruited. The district level received twenty two point eight (22.8\%) of the non-wage recurrent budget but had fifty nine point fifty-four percent (59.54\%) of total staff and consumes fifty seven percent (57\%) of the personal emolument budget. The difference was not substantial as "district level" included the main cities. The ratio of doctors to nurses (of all grades) in Accra was one is to thirteen (1:13), but in the northern region it was one is to twenty-three (1:23), which may be an indicator of rural/urban staff type differentials with a concentration of the better qualified professional staff in urban areas. ${ }^{66}$

Essentially, Samuel Adu-Gyamfi and Wilhelmina Donkoh (2013) discussed how notable diseases were controlled, prevented or cured in Asante during the period under review. They discussed the menace of malaria which was tackled by the colonial administration. They emphasized that the colonial administration in a bid to prevent and cure malaria which was a big threat to public health did not only make efforts to drain swamps, fill up pits and holes in the big towns including Kumase, but also quickly made available in all dispensaries, hospitals, clinics, drug stores and other health facilities, the tablets and syrups of quinine. ${ }^{57}$ This was obviously made in an attempt to promote the health of the people by tackling the health threat posed by malaria. They indicated that, provisions were also made for mothers

\footnotetext{
${ }^{52}$ Delanyo Devlo," the Health Sector Reform and Deployment, Training and Motivation of Human Resources towards Equity in Health Care: Issues and Concerns in Ghana", Ministry of Health, the Republic of Ghana, 2001.

53 Ibid.

$54 \mathrm{Ibid}$

55DelanyoDevlo," the Health Sector Reform and Deployment, Training and Motivation of Human Resources towards Equity in Health Care: Issues and Concerns in Ghana", Ministry of Health, the Republic of Ghana, 2001.

56 ibid

57Samuel Adu-Gyamfi and Wilhelmina Donkor', A historical review of diseases and disease prevention in the Gold Coast: A focus on Asante, from (1900-to1957),2013, pp 17-18
} 
who could not visit doctors or any health facility..$^{58}$ Explaining further, they described how every post office and postal agency in the country sold the government quinine tablets at a cheap rate. ${ }^{59}$ This was followed by a massive educational campaign which was embarked on through the use of radio broadcast and through opinion leaders to educate mothers, the young and the old on the correct usage of quinine. ${ }^{60}$ The emphasized that as part of the efforts to kick out malaria the use of mosquito nets was introduced by the colonial administration. ${ }^{61}$ They also strongly indicated how pregnant women and parents were admonished to sleep under mosquito nets with their children in order to prevent mosquito bites. ${ }^{62}$ This explicitly depicts how public health was organized in Asante during the colonial period.

In his PhD thesis, Samuel Adu-Gyamfi argued that:

Significantly, in spite of colonialism, the first half of twentieth century Asante saw a priestly caste who seriously engaged in indigenous medicine. Shrines and priests recorded a number of adherents. The priests began to make profit as a result of the increasing population of their devotees. For instance, any person who wished to be a co-worshipper or subject to a said Sumanhad to slaughter a fowl and deposit a sum of one pound and six shillings and when it caught any witch or wizard the sum of one pound, three shillings was received. It was also emphasized that in case of minor grievances the offender paid three pounds six shillings. In the case of witchcraft, the offender paid three pounds or the cost of a cow in the north. ${ }^{63}$

From the statement above, Adu-Gyamfi presented a clear picture of indigenous public health system that was operating during the colonial era. He explicitly showed the reality that the public health system or health care even during the colonial period was an admixture of herbs spirituality and western medical orthodoxy.

Adu-Gyamfi (2010) also noted in his study that: The quest for recognition and the need for indigenous healers to improve upon their service delivery as demanded by the British Colonial Administration necessitated the formation of traditional healers associations like the Society of African Herbalists, which was formed at Sekondi on 12th December, 1931 with its president being Kwesi Aaba. According to Adu-Gyamfi, their quest was to raise the local practice of -Medical Herbalism to a high and refined standard and to seek for a free and unhindered practice for its members. It has been noted that the Colonial Administration although came to terms with this fact they denied them the official recognition they wanted but made no attempt to suppress herbalist or any other indigenous healers. ${ }^{64}$

Adu-Gyamfi further elucidates that: In 1934, efforts were made by the Society of African Herbalists to rid the indigenous medical system of what has been described by the Colonial Administration as charlatanry, fraud and superstition. This was attributable to the fact that several of the practitioners in Asante engaged in some form of religious practices, either in the form of propitiation of deities or incantations.

According to the Colonial Administration, it was the ignorance of the indigenous people couched in a belief in magic and witchcraft that cannot be explained by reason which resulted into a state of fear. Specifically, members of The Society of African Herbalists were required to report all contagious diseases to government doctors. In spite of these efforts, the indigenous healers were refused an official license of recognition because the Colonial Administration hinted that there were verifiable heap of quack remedies in their practice.

From Adu-Gyamfi (2010), it is clear that traditional healing was considered unnecessary at that stage of the society's development. No wonder Adu-Gyamfi (2010) pointed out that, a colonial office circular dispatch, citing a suggestion made by Lord Hailey in an African survey that raised questions on studying native medicine, was rebuffed because the Medical Department lacked the resources to do so.

\footnotetext{
${ }^{58} \mathrm{Ibid}$

$59 \mathrm{lbid}$

$60 \mathrm{lbid}$

61 lbid

62 Ibid

${ }^{63}$ Adu-Gyamfi (2010), “A Historical Study of the Impact of Colonial Rule on Indigenous Medical Practices in Ashante: A Focus on Colonial and Indigenous Disease Combat and Prevention Strategies in Kumase, 1902-1957” $64 \mathrm{Ibid}$
} 
${ }^{65}$ In a different way, Prince Boakye Frimpong (2013) in his study titled "The Quest for Equity in the Provision of Health Care in Ghana" stated that following independence in 1957, effective social and welfare services were prioritized as a consequence of the devastating effect of colonialism on the health sector. The first national government revamped the health sector by enlarging and modernizing facilities as well as training more medical personnel. ${ }^{66}$ Frimpong, (2013), indicated that subsequently, Ghanaians could seek medical care in any government hospital, health center and pharmacy at zero financial cost as the health sector was financed by the State. Again quoting Senah (2001) Frimpong (2013) added that; "between 1957 and 1963 the number of health centers increased from ten to fortyone (10 to 41)", and of the $£ 144$ million that government budgeted, between 1963 and 1964, for projects, as part of public expenditure, about thirty-one percent (31\%) went towards the social services with much attention given to the health sector (p.85). Moreover, government's health expenditure increased from six point four percent (6.4\%) in 1965 to eight point two percent (8.2\%) in $1969 .{ }^{67}$ The above statistics from Frimpong (2013) makes it safe to conclude that the government spent more on the health care and human resource development compared to other departments during the period in question. ${ }^{68}$

\section{Public health in Asante (1902-1966)}

Ghana was a British colony for approximately one hundred years before independence in 1957 . Public health sector of every nation is undoubtedly very important if not the most important sector of that nation and Asante is no exception. Though it is also common knowledge that British rule brought modern or western health systems into the country, there is no need denying the outstanding reality that there were certain forms of health administrations in pre-colonial Asante before the introduction of modern medicine or western health systems into the country. The point must also be made that the Asante populace were health conscious and therefore engaged in various health practices before the introduction of orthodox medicine into the country.

Traditional medicine was prevalent in pre-colonial Ghana. The World Health Organization defines Traditional Medicine as diverse health practices, approaches, knowledge and beliefs incorporating plant, animal, and/or mineral based medicines, spiritual therapies, manual techniques and exercises applied singularly or in combination to maintain well-being, as well as to treat, diagnose or prevent illness (WHO, 2002; 2000) ${ }^{69}$ This was unarguably practiced by the people of pre-colonial Asante.

As cleverly put out by Razak Mohammed Gyasi et al (2011), and Addae Mensah (1992) as well as Curtis and Taket (1996), People from different cultural backgrounds have used different herbal plants, plant extracts, animal products and mineral substances as the means to care, cure and treat illhealth, with disease prevention, and with health promotion since pre-historic times..$^{70} \mathrm{It}$ is therefore an indubitable reality that modern or western medicine as introduced by the colonial masters into Asante was just an addition to the already existing and vibrant traditional health systems that existed before colonialism. ${ }^{71}$ The colonial health system was woefully insufficient, applied to a very small portion of the population of Ghana, in fact, was actually limited to only the colonial officials. It therefore means that the indigenous traditional medicine featured prominently even during the colonial period.

The health sector, after the immediate post-independence period, started addressing issues of equity in health care by expanding the availability of hospitals and health centres to cover much more of the countryside ${ }^{72}$. However, these facilities were still not equitably distributed. This action also coincided with the introduction of new cadres of health care workers such as Medical Assistants (or

\footnotetext{
$65 \mathrm{Ibid}$

66 Prince Boakye Frimpong, "The Quest for Equity in the Provision of Health Care in Ghana” 2013

$67 \mathrm{lbid}$

$68 \mathrm{lbid}$

69 World Health Organization; definition of Traditional Medicine, (2000, 2002)

${ }^{70}$ Razak Mohammed, Gyasi, et al, "Public Perceptions of the Role of Traditional Medicine in the Health Care Delivery System in Ghana" 2011

${ }^{71} \mathrm{lbid}$

72 Edward Brenya and Samuel Adu-Gyamfi, Interest Groups, Issue Definition and the Politics of Healthcare in Ghana, Public Policy and Administration Research, Vol.4, No.6, 2014
} 
Health Centre Superintendents), Technical Officers and Field Technicians for Diseases Control and Surveillance.

In his famous book "Towards Colonial Rule" Kwame Nkrumah (1962) saw Colonialism as the policy by which the colonial power binds her colonies to herself by politico-economic ties, which ultimately work to the advantage of the colonialist. ${ }^{73}$ It was through colonialism that western medical practices were regularly introduced to the Asante people. The history and development of biomedicine in this country can, therefore, be explained in part by the nature of the political and economic relationship that prevailed between the Gold Coast Colony and Britain. And also in part by the activities, contributions and impact of the various missionary groups that accompanied colonialism in Asante.

As observed by Jones Darkwa Amanor (2003), the completely alien tropical climate as it were to the Europeans, posed the greatest source of health hazards to the missionaries. ${ }^{74}$ It is believed that by the end of the first twenty years of the Basel Mission's presence in the Colony, for instance, half of the arrivals had died, including, one doctor who was sent to investigate into causes of the missionary deaths. ${ }^{75}$ At that time, since the advancement in medical science had not influenced tropical diseases, the missionaries described yellow fever, hepatitis, and malaria as tropical fever. ${ }^{76} \mathrm{~A}$ few of the missionaries also developed psychic disorders and died to culture shock and disillusionment. ${ }^{77}$

The earliest providers of health care for the missionaries were the health personnel in the castles along the coast. ${ }^{78}$ These were sent from Europe for the health needs of the colonial administrative staff, their native concubines and their mulatto children. ${ }^{79} \mathrm{~A}$ few also relied on herbalists some of whom saved some missionaries from dying from contracted diseases. ${ }^{80}$ After a long time, however, home missions sent doctors to the Colony. ${ }^{81}$ The clinics, which the Missions established became the basis for the development of a health delivery system for Asante. Today, the Mission hospitals, some of which are still supported from partners in Europe and America, still play an important role in the health delivery system of Asante. ${ }^{82}$

As soon as Ghana became Independent in 1957, the Nkrumah government did indeed take steps to improve the health conditions of Asante by formulating interesting and radical policies in the health sector. Some of these policies included the abolishing of the private service fees in the government hospitals as well as the establishment of free user medical services in the government hospitals. ${ }^{83} \mathrm{His}$ focus was also directed to the expansion of health care facilities across the country, making health care accessible and regional balanced. ${ }^{84}$ Several hospitals and community clinics were built by the Nkrumah Government as well as improvement in community sanitation across the country before his government was overthrown in $1966 .{ }^{85}$

\section{The colonial health services}

According to Kennedy A. Alatinga and John J. Williams (2014), the historical development of modern health care policy in Ghana (formerly, the Gold Coast) dates back to the 1920 . ${ }^{86}$ Kojo Senah (2001), also observed that the development of the colonial health service may be seen essentially in three major phases. ${ }^{87}$ The first phase (1471-1844) was characterized by medical apartheid whereby

\footnotetext{
73 Nkrumah K, Towards Colonial Freedom, Kingswood survey, The Windmill Press Ltd.

74 Jones Darkwa Amanor, (2001), Pentecostalism in Ghana: An African Reformation, 1962, pp - 12-13

75 Ibid

76 Ibid

77 lbid

78 Ibid

$79 \mathrm{lbid}$

$80 \mathrm{lbid}$

81 lbid

82 Ibid

83 Edward Brenya and Samuel Adu-Gyamfi, Interest Groups, Issue Definition and the Politics of Healthcare in Ghana, Public Policy and Administration Research, Vol.4, No.6, 2014, (ISSN 2224-5731).

84 ibid

$85 \mathrm{Ibid}$

86 Kennedy A. Alatinga and John J. Williams, Development Policy Planning In Ghana:

The Case Of Health Care Provision, European Scientific Journal, November 2014 edition vol.10, No.33

${ }^{87}$ KojoSenah, "In Sickness and in Health: Globalization and Health Care Delivery in Ghana, 2001.
} 
white settlers were physically segregated from the local population and given medical coverage. ${ }^{88}$ The second phase of the colonial health service according to Senah (2001) was born when health coverage was extended to African domestic servants and those in the colonial civil and military service. ${ }^{89}$ Towns with a sizeable European presence were provided with piped water, a drainage system, and other sanitary facilities..$^{90}$ In 1868 the first hospital was built at Cape Coast (then the colonial capital) and subsequently rural dispensaries were built in several localities. ${ }^{91}$

Senah (2001) added however that the new medical dispensation did not have an easy beginning. The local people approached it cautiously while utilizing their indigenous healing systems. In an attempt to neutralize the influence of healers and to promote the new health dispensation, in 1878 the Native Customs Regulation Ordinance was passed. ${ }^{22}$ The passage of the Native Customs Regulation Ordinance banned traditional healing and all other indigenous practices, which offended Western sensibilities..$^{93}$

African civil servants were compelled to obtain a certificate of disability from colonial medical officers only. ${ }^{94}$ And Christian converts were threatened with ex-communication if found to have consulted traditional healers. ${ }^{95}$ According to Senah (2001) the last phase of the colonial health service was born when Asante was defeated in 1901 followed by the annexation of the northern territories. ${ }^{96}$ Under the governorship of Gordon Guggisberg there was rapid expansion in the provision of infrastructural facilities. ${ }^{97}$ Under his reign, Korle-Bu Hospital was built in 1923 for use by Africans and for research into tropical diseases. The Colonial medical service was largely curative although in the $1930 \mathrm{~s}$ a Sanitary Brand was set up to oversee public health. ${ }^{98}$ It was also urban-biased and fees were charged. Thus, even at the height of the colonial medical service not more than 10 percent of the population had access to allopathic care. ${ }^{99}$

According to Simpson (1909), the policy of Health care in the Gold Coast, has been to provide an European quarter in order that the risk of malaria infection from the insanitary conditions of native houses and from infected natives may be reduced. ${ }^{100}$ Following the signing of the Bond of 1844 between the British and some local chiefs, relative peace was ensured in the colony and this enhanced European commercial and Christian missionary activities in the hinterland..$^{101}$ It soon dawned on the Europeans that their health could no longer be guaranteed unless the health needs of the local population were also met. ${ }^{102}$

Again, Ayinnam (1989) observed that the provision of health care services was initially limited to colonial administrators, officials of mining companies, merchants and other Europeans. That Health services were later extended to only zero point zero two percent (0.02\%) of the African Population and most of this population worked in the civil and public services such as the police. ${ }^{103}$ The era before independence, funding of healthcare was the sole prerogative of the colonial government or the missionaries where they involved in the provision of healthcare at that time. ${ }^{104}$

In a health research report on the "Impact of Structural Adjustment Programme (SAP) on Availability of and Access to Health Care in Chana" and published by the Structural Adjustment

\footnotetext{
$88 \mathrm{Ibid}$

$89 \mathrm{lbid}$

$90 \mathrm{lbid}$

91 lbid

$92 \mathrm{lbid}$

$93 \mathrm{lbid}$

94 Ibid

95 Ibid

$96 \mathrm{lbid}$

$97 \mathrm{lbid}$

98 Ibid

99 lbid

${ }^{100}$ Simpson W. I., Sanitary matters in the Various West African Colonies and the Outbreak of plagues in the Gold Coast. London: Crown Agents, 1909.

$101 \mathrm{lbid}$

102 Ibid

${ }^{103}$ Anyinam, C. A. The Social Costs of the International Monetary Fund's Adjustment Programs for Poverty: The Case of Health Care Development in Ghana. International Journal of Health Services, 1989, pp 531-547.

104 Ibid
} 
Participatory Review Initiative (SAPRI) in April, 2001, an observation was made that indicated that the late 1950 and early 1960 s Ghana had one of the highest levels of income and some of the best social and economic infrastructure in sub-Saharan Africa. ${ }^{105}$ Citing Widstrand 1969, Sowa 1993 and Bonsi 1996, the SAPRI Research Report was clear that until 1983, Ghana's healthsystem was financed mainly out of the national budget ${ }^{106}$ The observation as contained in the report does not only affirm the point as noted earlier that the western health care system was limited and reserved for only a particular class of people during the colonial period, but has also thrown more light on how the health sector was budgeted and financed in Ghana immediately after independence. ${ }^{107}$

The (SAPRI) report observed further that: The world economic recession of the early-to-mid 1980s, however, led to a decline in Ghana's economy. ${ }^{108}$ One indirect result was the fall in government expenditure on health care from six point forty- five percent $(6.45 \%)$ of the budget and zero point ninety-five percent (0.95\%) of gross domestic product (GDP) in 1980, to four point thirty-eight percent (4.38\%) and zero point thirty-five percent (0.35\%) respectively in $1983 .{ }^{109}$

The report states among other things that:

In order to arrest the situation, the government adopted a set of economic policies in a structural adjustment programme (SAP) that aimed to create a liberal socio-economic and political environment. The policies also sought to reduce government spending, notably on social services, and encouraged a change in the central government's role as the main provider and financier of health services in Ghana. The introduction of user fees and charges for health services has meant that some people are excluded by reason of poverty or unwillingness to pay. Whilst the extent of this is unknown, it can be assumed that many people have difficulty in paying, bearing in mind the recent World Bank estimate that $35 \%$ of Ghanaians live below the poverty line. ${ }^{110}$

Anyinam (1989) asserts that formal planning of health care services in Ghana started in the 1920 under the leadership of Governor Gordon Guggisberg when the colonial government established an effective medical policy, which instituted freehealth care for European officials. ${ }^{111}$ Consistent with the concept of financial accessibility, in 1930, a proportional user-fee system was introduced in the Gold Coast for people seeking health care in public facilities. ${ }^{12}$ In this direction, lower fees were charged for the lower income groups, mainly formal sector employees. This proportional user-fee system however, did not clearly address informal sector workers and how their incomes were assessed for the proportional user-fee policy to be applied appropriately. ${ }^{113}$

Konotey-Ahulu et al (1970), observed that under the colonial health policy, medical practitioners were allowed to charge private professional fees despite the fact that they worked in government health facilities. ${ }^{114}$ Because of user-fee policy, by 1954 , patients seeking health care at government facilities were required to pay dispensary fees and the cost of any drugs dispensed as well as professional fees, thus creating financial barriers to access health care. ${ }^{115}$ However, it is important to note that the colonial health policy did exempt the very poor from paying any forms of user-fees at all government health facilities. Meanwhile, the policy of free health care for the very poor was never accompanied by any clear criteria for the identification of these very poor people for effective implementation of the policy. ${ }^{116}$ The determination of who were very poor and who were not was left to the personal interpretations of colonial medical staff. For instance, Konotey-Ahulu et al. (1970) indicate that the decision as to whether any charges were made or not was left to the discretion of the

\footnotetext{
${ }^{105}$ SAPRI report April, "Impact of SAP on Availability of and Access to Health Care in Ghana” 2011

106 Ibid

$107 \mathrm{lbid}$

108 Ibid

109 Ibid

110 lbid

${ }^{111}$ Anyinam, C. A. The Social Costs of the International Monetary Fund's Adjustment Programs for Poverty: The Case of Health Care Development in Ghana. International Journal of Health Services, 1989, 19(3), pp 531-547

${ }^{112}$ Ibid

$113 \mathrm{lbid}$

${ }^{114 K o n o t e y-A h u l u, ~ F . ~ I . ~ D ., ~ O c l o o, ~ E ., ~ A d d y, ~ P . ~ M ., ~ B a m f o r d, ~ A . ~ M ., ~ \& E n n i n, ~ C . ~ R e p o r t ~ o f ~ t h e ~ c o m m i t t e e ~ a p p o i n t e d ~ t o ~ i n v e s t i g a t e ~}$ Hospital fees. Accra-Ghana: Ministry of Health, 1970.

${ }^{115}$ Ibid

${ }^{116}$ Ibid
} 
medical officer in charge of the dispensary, subject to the discretion of the Director of Medical Services. ${ }^{177}$ This practice of giving interpretative leverage to medical officers remained till 1957 when Ghana gained independence from Britain. ${ }^{118}$

\section{The post-colonial situation}

Immediately after independence in 1957, Dr. Kwame Nkrumah, the first President of Ghana made it a priority to improve health services in the country. This was made manifest by the following statement: "My first objective is to abolish from Ghana poverty, ignorance and disease. We shall measure our progress by the improvement in the health of our people. The welfare of our people is our chief pride, and it is by this that my government will ask to be judged"119

Motivated by his vision to make a very comfortable society for all, Nkrumah radically transformed the Ghanaian economy based on socialist ideals and egalitarian principles. To this end, his first major policy action in the health sector was to quickly abolish private practice in government health facilities especially hospitals, where the practice was common. ${ }^{120}$ Konotey-Ahulu et al. (1970) observed that on September $1^{\text {st }} 1958$, Nkrumah's government withdrew "the privilege of private practice from all medical doctors and dentists Consequently, for the first time in the country, patients whether Ghanaian or non-Ghanaian, stopped paying professional fees in government health facilities. ${ }^{121}$

Indeed in 1961 basic education was made free and compulsory and in the following year health services in public institutions were also made virtually free. Between 1957 and 1963 the number of health centres increased from one (1.0) to forty (41). ${ }^{122}$ However, this policy put a heavy burden on the economy. ${ }^{123}$ Available statistics on central government expenditure for $1963 / 64$ show that of the projected public expenditure of $£ \mathrm{G} 144$ million, about thirty-one percent (31\%) was earmarked for social services at a time when cocoa, the nation's main foreign exchange earner, had suffered massive a fall in price on the work market. ${ }^{124}$ Thus even though Ghana's cocoa production doubled by over 200 percent from 1956 to $1964 / 65$, this fetched the country a mere increase of seven point seven percent $(7.7 \%)$ in revenue. ${ }^{125}$ According to Birmingham et al (1996), International manipulation to cripple the then government was suspected to be at play in this scenario. ${ }^{126}$ The resultant financial strain compelled government to impose stricter control on foreign, exchange outflow, resulting in the shortage of goods. ${ }^{127}$ In the public health institutions, the economic difficulties of the country and the 'dark side' of a free medical service both manifested themselves forcefully; also medicines meant for hospitals found their way into the open market. Mismanagement and pilfering became the norm. ${ }^{128}$

Konotey-Ahulu et al., (1970), observed that, with the abolition of private fees in government health facilities, financial access to health care was improved because hospital charges were drastically revised downwards. ${ }^{129}$ For instance, with respect to midwifery services, women delivering in government hospitals, spending ten days and beyond, were charged only $£ 1.00$ as daily maintenance charges; children of 16 years and below were treated free of charge; government official employees, public and civil servants and all workers were entitled to free medical care at out-patients clinics. ${ }^{130}$

Subsequently, Nkrumah instituted a free health care policy for all persons living in Ghana at all public health facilities by 1965. Arhinful, (2003), pointed out that this free health care policy was

\footnotetext{
117 lbid

${ }^{118}$ Ibid

119 Rooney, D., Kwame Nkrumah: vision and tragedy. Legon, Accra, Ghana: Sub-Saharan Publishers, 2007.

${ }^{120} \mathrm{lbid}$

${ }^{121}$ Konotey-Ahulu, F. I. D., Ocloo, E., Addy, P. M., Bamford, A. M., \&Ennin, C. (1970). Report of the committee appointed to investigate Hospital fees. Accra-Ghana: Ministry of Health

${ }^{122} \mathrm{lbid}$

123lbid

124 Ghana Statistical Service. (1988a). Ghana Demographic Health Survey (GDHS, 1988). Accra-Ghana: Ghana Statistical Service.

$125 \mathrm{Ibid}$

${ }^{126}$ Birmingham, W., I. Neustadt, and EN. Omaboe, Ed. A Study of Contemporary Ghana, Vol 1: The Economy of Ghana, London; George Allen and Unwn Ltd, 1966.

$127 \mathrm{lbid}$

128 libid

${ }^{129129}$ Konotey-Ahulu, F. I. D., Ocloo, E., Addy, P. M., Bamford, A. M., \&Ennin, C. Report of the committee appointed to investigate Hospital fees. Accra-Ghana: Ministry of Health, 1970.

$130 \mathrm{lbid}$
} 
financed mainly from the state's tax revenue thanks to flourishing cocoa prices on the international market and huge $\$ 481$ million foreign reserves. ${ }^{131}$ The objective of the free health care policy was to prevent households or individuals from falling into poverty as a result of paying out-pocket for health care. ${ }^{132}$ As a result, hospital fees and all charges were abolished at all government health facilities, allowing even the poor to access formal health care. ${ }^{133}$ Nkrumah's free health care policy aimed to address the problem of urban bias in the distribution of health resources geographically. ${ }^{134}$ For this reason, there was a massive expansion of health facilities across the country with a focus on the rural areas. Senah, (1989) cited in Arhinful, (2003), observed for instance that, between 1960 and 1966, thirty-five (35) new rural health centres were established in Ghana to meet the growing demand for health care in the country. ${ }^{135}$

Notwithstanding all these efforts by the Nkrumah Government in the area of health delivery in Ghana, Twumasi (1981) bluntly indicate that the problem of unbalanced distribution of health resources was insignificantly addressed because health care was not readily available for those who needed it especially in most rural areas. ${ }^{136}$ Twumasi's further argues that though twenty-three percent (23\%) of the population lived in the urban areas then, seven-six percent $(76 \%)$ of doctors practiced there. ${ }^{37}$ Twumasi postulates that the cadre of health professionals who emerged in the newly independent country were very powerful because of their prestige, scarcity, and social contacts with political decision-makers to determine where to work. ${ }^{138}$ Anyinam (1989) substantiate this claim, by indicating that by 1960 there was one physician to every twenty-one thousand six hundred $(21,600)$ patients while the ratio of nurses to patients was one nurse to every five thousand four hundred and thirty $(5,430)$ patients in the rural areas. ${ }^{139}$ Most rural dwellers thus relied on the use of traditional medicines, herbs and concoctions to treat their ailments. ${ }^{140}$

It is therefore clear that the benefits or successes of free financial access to health care were negated by the still unbalanced geographical distribution of health facilities and the unavailability of health staff at the rural areas to administer to the rural people. ${ }^{141}$ According to the World Bank (2012:17), infant and maternal mortality rates were very high in the rural areas. The report further argues that in 1960 under- five (5) child mortality was as high as two hundred and eighteen (218) per one thousand $(1,000)$ live births. Consequently, life expectancy only marginally increased to forty-six (46) years from the base year of forty-four (44) years in $1957 .{ }^{142}$

However, despite these short-comings and criticisms that the policy was "overgenerous" and led to financial drain on tax revenue, Konotey-Ahulu et al. (1970), observed that, Nkrumah's free health care policy remained in force until 1966 when Nkrumah's government was toppled in the first military coup in the country ushering in the military government of the National LiberationCouncil (NLC) led by Lt. General Ankrah. ${ }^{143}$

A careful observation and analysis of the colonial heath policy reveals that geographically, the colonial health policy was biased toward those living in urban areas. According to Twumasi (1981), colonial health was simply urban-oriented. ${ }^{144}$ Twumasi argues that even though the colonial health

\footnotetext{
${ }^{131}$ Arhinful, D. K. The Solidarity of Self-Interest. Social and Cultural Feasibility of Rural Health Insurance in Ghana. Africa Studies Centre, Research Report 71/2003. Africa Studies Centre, 2300 RB Leiden, 2003.

132 Ibid

133 Ibid

134 Ibid

$135 \mathrm{Ibid}$

${ }^{136}$ Twumasi, P. A. Colonialism and international health: A study in social change in Ghana. Social Science \& Medicine. Part B: MedicalAnthropology, 15(2), 1981, 147-151. doi:10.1016/0160-7987

137 Ibid

138 Ibid

139 lbid

${ }^{140}$ Anyinam, C. A. The Social Costs of the International Monetary Fund's Adjustment Programs for Poverty: The Case of Health Care Development in Ghana. International Journal of Health Services, 1989, 19(3), pp 531-547.

141 Ibid

142 World Bank Report on Health, 2012, pp - 17

${ }^{143}$ Konotey-Ahulu, F. I. D., Ocloo, E., Addy, P. M., Bamford, A. M., \&Ennin, C. Report of the committee appointed to investigate Hospital fees. Accra-Ghana: Ministry of Health, 1970.

${ }^{144}$ Twumasi, P. A. Colonialism and international health: A study in social change in Ghana. Social Science \& Medicine. Part B: MedicalAnthropology, 15(2), 1981, 147-151. Doi: 10.1016/0160-7987(81)90037-5.
} 
policy discouraged the use of traditional medicine, formal health facilities were concentrated in a few urban towns, where the colonialists were engaged in commercial and mining activities whereas the rural areas were without modern health facilities. ${ }^{145}$ Anyinam, (1989) points out that the "colonial health policy was characterized by a gross regional misdistribution of health facilities. ${ }^{146 "}$ " For example, out of thirty-nine (39) hospitals in the country in 1927/28, eighty-seven percent (87\%) were located in the more urban and resource rich southern parts of the country leaving only thirteen percent $(13 \%)$ in the more rural, resource-poor northern regions of the country. ${ }^{147}$

Anyinam (1989) again claims that by 1953 , about ninety percent (90\%) of hospital beds were in the south. For example, the population to bed ratios ranged from four hundred and seventy-eight is to one (478:1) in the south to thirty five thousand is to one (35000:1) in the north. ${ }^{148}$ Building his argument on this point, Arhin (2003) points out that even the few health facilities established in the urban towns routinely experienced overcrowding at hospitals and dispensaries plus inadequacy of medical staff and deterioration of sanitary conditions. ${ }^{149}$ Christian missionaries contributed immensely to the historical development of health care policy in Ghana. ${ }^{150}$ Arhin (2003) further argues that unlike the colonialists, the missionaries established their health facilities in the rural areas in their desire to win converts to Christianity. ${ }^{151}$ To this end, the contribution of missionaries to health care delivery in Ghana started in 1931 when the Basel Missionaries established the Agogo hospital in Ashanti Akim in the south. ${ }^{152}$ In 1943 , the Catholic Missionaries also built the BremanAsikuma hospital also in the south, and in 1951 the Jirapa hospital in the north, and the Worawora hospital in the south respectively were added. ${ }^{153}$ These mission health facilities operated on cost recovery, and as such, the full cost of drugs was passed on to users but exemptions were granted to the very poor. ${ }^{154}$ Because the missionaries operated in rural settings, their ability to identify the very poor was enhanced by the fact that at rural level, people were likely to know one another. ${ }^{155}$

\section{Public health in Asante during the colonial and post-colonial period: expatiating primary and secondary sources}

Oral tradition of Asante has shown that poor health and diseases were considered as barriers to economic fortune and all epidemics or outbreaks in the society should be studied in order to find out their cause or causes including social causation. ${ }^{156}$ Norms and myths were used as social mechanisms to promote public health in the pre-colonial Traditional Society in Asante. ${ }^{157}$ For example, if one is bathing, he/she does not sing in the bathroom. ${ }^{158}$ This is because, singing per say, is not a misdemeanor, but the soap contains toxic substances that can make you fall sick if it gets into your system or if you swallow it and as a matter of fact, myth is used to prevent one from doing so. 159

Traditional Public Health was in the hands of traditional healers, herbalists and the "fetish" priests. ${ }^{160}$ Outbreaks of diseases was seen as the wrath of gods and needed to be pacified and find out the causes and the remedies to the outbreaks. In these cases, libations were poured and the gods were

\footnotetext{
145 ibid

${ }^{146}$ Anyinam, C. A. (1989). The Social Costs of the International Monetary Fund's Adjustment Programs for Poverty: The Case of Health Care Development in Ghana. International Journal of Health Services, 1989, 19(3), pp 531-547.

147 Ibid

148 Ibid

149 Arhinful, D. K. (2003). The Solidarity of Self-Interest. Social and Cultural Feasibility of Rural Health Insurance in Ghana.Africa Studies Centre, Research Report 71/2003. Africa Studies Centre, 2300 RB Leiden

$150 \mathrm{Ibid}$

151 lbid

$152 \mathrm{lbid}$

153 Ibid

$154 \mathrm{Ibid}$

$155 \mathrm{Ibid}$

${ }^{156}$ An interview with Dasebre Nana OtuoSerebou, Omanhene of Juabeng Traditional Area, at his residence in Juabeng, on $25^{\text {th }}$ March, 2016, around 4:00pm

$157 \mathrm{lbid}$

158 Ibid

$159 \mathrm{lbid}$

$160 \mathrm{lbid}$
} 
asked to redeem the people from the bad situation ${ }^{161}$. And if anyone was found guilty to the cause of the outbreak, that person was punished accordingly. ${ }^{162}$

Asante managed diseases by traditional healers, herbalists and chief priests and priestess before the coming of the Europeans. ${ }^{163}$ Adu-Gyamfi, added that no matter how the outbreak could be, it was still attributed or explained in causative terms. ${ }^{164}$ With that in mind, leaders in the pre-colonial era continued to adopt policies to manage the public health needs of the people. ${ }^{165}$

The diseases that were common and cause havoc or even nearly an epidemic at the time included, small pox, malaria, sleeping sickness (trypanosomiasis), cannier rabies, meningitis, onchocerciasis among a host of others.

Sometimes diseases were brought to the Asante kingdom by people coming from the neighbouring countries. ${ }^{166}$ This attestation is buttressed by an archival document on the infectious diseases return for the week ending on $22^{\text {nd }}$ June 1946, which cited for instance that one Mr. Salifu Basare from Burkina Faso came to Ejura Zongo while carrying smallpox disease and infected Mr. Lamptey who happened to be a driver and also infected his eight-year old child, Ayeley. ${ }^{167}$ In order to prevent these kinds of instances from occurring, the Assistant Director of Medical Services at the time, Dr. Mackenzie ordered for health screening at the border towns for people coming from the neighbouring countries. ${ }^{168}$

In 1946 a weekly report by the senior Health officer of Asante to the Assistant Director of Health, Medical Services Accra, dated 22 June, 1946, revealed that the number of outbreaks of diseases such as small pox, tuberculosis, trypanosomiasis and pneumonia in towns such as Kumasi, Mampong, Bekwai and Oboasi. ${ }^{169}$ The table below illustrates a summary of the report.

Table 1:

\begin{tabular}{llll}
\hline Weekly Report of diseases in Asante & & \\
\hline Town & Disease & Number of cases & Number of deaths \\
Kumasi & Tuberculosis & Nine (9) & Four (4) \\
& Trypanosomiasis & One (1) & - \\
Mampong (Ejura) & Pneumonia & Three (3) & - \\
Oboasi & Small pox & Two (2) & - \\
& Tuberculosis & Four (4) & - \\
\hline
\end{tabular}

Source: Kumasi Cultural Center Archives ${ }^{170}$

Earlier on, there were already reported cases of small pox epidemics in many suburbs of Asante in the 1930s, such as Oboasi, Keyansi, Ofinso and Kumasi. ${ }^{171}$ For instance in a memorandum from the Senior Sanitary officer of Asante to the Chief Commissioner of Asante, dated $14^{\text {th }}$ December, 1929, the case of the outbreak of small Pox at Osino and Anyinam which were under Asante at that time was reported. Though the number of cases of the outbreak was not reported in the document, the memorandum states:

I have the honour to report that I have been informed that small pox has broken out at Osino and Anyinam on Accra line.

2. And all possible precautions have been taken to protect Asante

\footnotetext{
$161 \mathrm{lbid}$

162 Ibid

${ }^{163}$ Views from Dr. Adu-Gyamfi, at EHC, KNUST CAMPUS, on $14^{\text {th }}$ April, 2016, around 3:00pm

$164 \mathrm{lbid}$

165 ibid

${ }^{166}$ An interview with Madam Regina Wilson, a Public Health Nurse at KNUST Hospital, on $12^{\text {th }}$ April,2016, around 1.30 pm, at Knust Hospital.

167PRAAD, Kumasi, ARG 2/14/16, Infectious Diseases return for the week ended, 22 June, 1946

168 Ibid

169 PRAAD, Kumasi, ARG 2/14/16, Infectious diseases return for the week ended, 22 June, 1946

170 Ibid

171PRAAD, Kumasi, ARG 6/14/21, Outbreak of small pox at Osino and Anyinam
} 
3. The deputy director of sanitary service has asked for the closure of the stations at Osino and Anyinam for the passengers' traffic which should do much to remove and threats to south East Asante. ${ }^{172}$

The memorandum is a clear confirmation of the outbreak of small pox in Asante and how it was combatted, though it did not state the specific number of cases of the outbreak. Also in the early 1950,s shortly before independence, there were a number of small pox cases reported in Asante. They were a lot of cases recorded on the outbreak of the small pox epidemic from 1950 to 1954. Table 2, below shows the comparative analysis of the epidemic within the period under review. ${ }^{173}$

Table 2: Yearly report of the cases of small pox in Asante from 1950 to 1954

\begin{tabular}{lrr}
\hline Year & Number of cases & Number of deaths \\
\hline 1950 & 99 & 14 \\
1951 & 4 & - \\
1952 & 7 & 1 \\
1953 & - & - \\
1954 & 13 & 2 \\
\hline
\end{tabular}

Source: Kumasi Cultural Center, Archival Document, no. ARG 2/14/2/1. ${ }^{174}$

\section{Emphasis on the colonial disease prevention strategies to cure in Asante}

The colonial government adopted a lot of measures and formulated many policies to check the issue of public Health in Asante. The efforts or the measures that were taken regarding Public Health were dependent on the nature of the threat they confronted. Among the efforts that were made included vaccination, health week Symposium, health education, provision of health centers, training of health personnel, among a host of others. Vaccination was a common approach used to tackle the issue of Public Health in Asante. It was usually done according to households, personnel were recruited to go through houses to vaccinate to cure or prevent infections or diseases. In addition to vaccinations within Asante, seven (7) vaccination teams were formed to deal with the following barriers: ${ }^{175}$

1. Kumai-Tamale Road

2. Kumasi-Wenchi Road

3. Kumasi - Cape Coast Road

4. Kumasi - Bibiani Road

5. Kumasi - Accra Road, and the last two teams to deal with Western Frontier including the Soko and DormaaAhenkro Preventive Stations. ${ }^{176}$

It is worth noting that the teams were all placed under the direct supervision of the Head Superintendent in Asante. ${ }^{177}$ Below is a table showing the number of people in Asante who were vaccinated for small pox and the number of people who availed themselves again for inspection from 1950 to 1954 .

Table 3: Smallpox vaccinations

\begin{tabular}{lrrrrr}
\hline Year & $\begin{array}{r}\text { Total number } \\
\text { of vaccination }\end{array}$ & $\begin{array}{r}\text { Number seen again } \\
\text { for inspection }\end{array}$ & $\begin{array}{r}\text { Number } \\
\text { successful }\end{array}$ & $\begin{array}{r}\text { Number not } \\
\text { successful }\end{array}$ & $\begin{array}{r}\text { Number } \\
\text { unknown }\end{array}$ \\
\hline 1950 & 73695 & 6133 & 17832 & 654 & 49040 \\
1951 & 16387 & 4126 & 11416 & 299 & 8876 \\
1952 & 24463 & 2337 & 6037 & 350 & 8021 \\
1953 & 21366 & 831 & 4716 & 239 & 7142 \\
1954 & 52819 & 5870 & 17637 & 727 & 28585 \\
\hline
\end{tabular}

Source: Kumasi Cultural Center, Achives Document, no. ARG 2/14/2/1. ${ }^{178}$

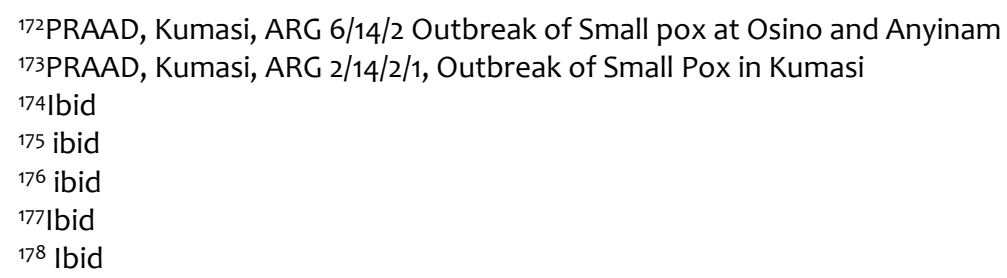


Several Vaccination centers were also created within Asante to promote Public Health in the Region. Figure one below is an archival document from the Kumasi Cultural center, listing the vaccination centers that were created in the attempt to promote public Health in Asante. ${ }^{179}$

\section{Public Health Legislations and Regulation}

There are a number of legislations and regulations enacted by the colonial government to help promote public health in Asante. ${ }^{180}$ For instance, 1936 , regulations were made by the colonial government to check diseases of animals such as carnine Rabies in Asante. ${ }^{181}$ There were rules, legislations, bye-laws, ordinances, statutes and regulations that were enacted to ensure public Health in Asante.

\section{Establishment of the Health Week}

In 1929, Health Weeks were observed in Asante as parts of efforts to promote public health in the Region. There were also a lot of safety measures adopted in the public prisons in Asante to help prevent the spread of small pox in Asante. ${ }^{182}$ There were other precautions or measures that were adopted in 1949 to help promote public health in Kumasi prisons.

\section{Construction of Latrines as a form of public health precaution in Asante}

Public Latrines were constructed in various towns to improve hygiene in Asante. This in the long run contributed to the proper administration of public Health in Asante. The table below shows some of the towns and the number of latrines that were constructed to improve public health in colonial Asante

Table 4: Towns and the number of latrines that were constructed

\begin{tabular}{lrrrrrrrrr}
\hline $\begin{array}{l}\text { Name of } \\
\text { town }\end{array}$ & Beposo & Banko & ManpongAkronfuso & Oyoko & Juabeng & Kasam & Safo & Ntonso Odumase \\
\hline $\begin{array}{l}\text { Number } \\
\text { of latrine }\end{array}$ & 3 & 3 & 2 & 2 & 2 & 2 & 2 & 3 & 3 \\
\hline
\end{tabular}

Source: Kumasi Cultural Center Archives

\section{The post-colonial period in Asante up to 1966}

There were many measures adopted by the Nkrumah government to address the numerous public health issues confronting the whole country and Asante was no exception. One notable measure which features prominently with all prevalence when it comes to the development of public Health in Asante by the post-colonial Nkrumah government is the promotion and improvement of the midwifery sector of the Ghana health service. ${ }^{183}$ The Nkrumah Government built a lot of midwifery facilities in many communities in Asante land. Some of the towns, villages or communities that benefited from this policy include: Tafo, Asokwa, Oboasi, Effiduase, Kumawu, Manpong, Agona, Nsuta, Bekwai, Offinso, Kenyansi, Kokofo, Ejisu, Odumase, Konogo, Nkawie, Antoakrom, Kuntanase, Wiamoase, Akrokerri and many more. ${ }^{184}$

The post-independence government was not confronted with the problem of defining health care as scientific or modern way of providing health care. ${ }^{185}$ However, the main concern was to establish the requisite type of financing health care in Asante. ${ }^{186}$ Therefore Nkrumah's government through the influence of health care interest groups suggested equitable distribution of public health

\footnotetext{
179PRAAD, Kumasi, ARG 2/14/60, List of Vaccination centers in Asante

180PRAAD, Kumasi, ARG 1/14/5/7, Kumasi Public Board Ordinance, $10^{\text {th }}$ December 1934

181PRAAD, Kumasi, ARG 6/14/2, Regulations made by the Governor in Council under Section 17 of the Diseases of Animals Ordinance, 1936.

182PRAAD, Kumasi, ARG2/14/29, Outbreak of small pox in Kumasi Prison

183PRAAD, Kumasi, ASH, 18b. 1957. Improvement on Midwifery after Independence.

184lbid

185Interview with Dr. Edward Brenya, Department of History and Political Studies, KNUST. 14 ${ }^{\text {th }}$ April, 2016, 1:00 pm.

186 Ibid
} 
to all citizens including those in Asante. ${ }^{187}$ There is no disputation concerning the fact that the health sector of every country is very important since it has a knock-on effect on the performance of other sectors. It is also a reality that public health policies of all countries are aimed at improving the health status of the masses or the communities and not individuals. Public Health in Ghana has come a long way, starting from the pre-colonial period, through the colonial period to the post-colonial period. There are therefore remarkable continuities and changes experienced in the public health sector of Ghana.

By the introduction of orthodox medicine by the colonial masters coupled with political domination which toppled Asante hegemony, the indigenous health delivery system undergone certain changes and discontinuities. The Western Medicine for instance introduced the building of public health facilities at various big cities and towns to cater for the needs of the people. But it is worth noting that these health facilities built by the colonial masters were restricted in usage to only the whites. The indigenous people who were not allowed initially to benefit from these facilities had no choice than to remain calm and concentrate on their traditional form of health care. This means that even during the colonial period, where orthodox medicine was introduced, traditional medicine and health care was still very popular among the Asante and therefore dominated the western form of medical care.

However, by the 1920s, orthodox medicine began to gain some kind of popularity especially when certain pragmatic and deliberate measures were taken to stop the practice of traditional form of medical care in Ghana. Some of these deliberate measures included rules and regulations adopted by the colonial masters that targeted at crippling indigenous healing practices in not only Asante but other parts of the country. A typical example is the passage of the Native Customs Regulatory Ordinance in 1878. The passage of this ordinance was meant to neutralize the influence and popularity of traditional healing and promote the new health dispensation. And this actually succeeded in promoting significantly the orthodox medical care system which was vigorously introduced by the colonial masters.

Several policies, strategies and measures were adopted by the colonial government to promote health care delivery and prevent the spread of diseases in Ghana and Asante for that matter. Prominent among these policies and measures include the expansion of the health care system by the provision of several infrastructures and the building of many health facilities at vantage areas. In Asante for instance, several hospitals and clinics were built. For instance, the colonial government instituted several pragmatic measures such as the provision of latrines at various parts of Asante, the adoption of health weeks exercise, the cleaning and the screening of the prisons, periodic vaccinations and among others. All these were done by the colonial government to promote public health and prevent the spread of infectious diseases in Asante.

\section{Conclusion}

It can be deduced that Ghanaians in general and for that matter Asante were already very conscious of their health and therefore had a lot of health proverbs, myths and practices before the introduction of orthodox medicine and health care system in the fifteenth century.

Secondly, it can be deduced that before the newly introduced western health system could be widely accepted by the indigenous people, it had to take among other things, deliberate measures and policies adopted to neutralize the influence of traditional healing practices in the country.It was also clear that the colonial masters after they succeeded in introducing and forcing their new form of medical system on the indigenous people did a lot to promote public health in Asante and other parts of the country.It can also be concluded that the post-colonial government under Nkrumah adopted several public health measures such as the free health care policy and expansion of midwifery care to promote maternal health care in Asante until his overthrow in 1966.

In a nutshell, the issue of public health care in Asante dates back to time immemorial. This continued till the European advent in the fifteenth century when they continued to add to the advancement of the public health of the people till their exit in 1957 when the Nkrumah government had the opportunity to also bring on board several policies that improved the public health situation in Asante and Ghana as a whole before the overthrow of Nkrumah 1966.

187 Ibid 


\section{References}

Adam, Francis. (1891) he Genuine Works of Hippocrates, William Wood and Company, New York, (1891).

Adu- Gyamfi, Samuel, Adjei, P-OW, Owusu- Ansah, Daniel (2013). "Preventive healthcare strategies and impact among the Asante people of the early twentieth century Gold Coast: A historical narrative and lessons for the present sanitation challenges in Kumasi", Journal of studies in social sciences, Volume 5, No.2 www.infinitypress.info

Adu-Gyamfi Samuel (2010), "A Historical Study of the Impact of Colonial Rule on Indigenous Medical Practices in Ashante: A Focus on Colonial and Indigenous Disease Combat and Prevention Strategies in Kumase, 1902-1957"

Adu-Gyamfi, Samuel., Donkoh, W.J (2013) "Historical Review of Diseases and Diseases Prevention of Gold Coast" focus on Asante (1900-1957)", Historical Research Letter, volume 5,

Amanor Darkwa J,. (1962) Pentecostalism in Ghana: An African Reformation.

Anyinam, C. A. (1989). "The Social Costs of the International Monetary Fund's Adjustment Programs for Poverty: The Case of Health Care Development in Ghana." International Journal of Health Services, 19(3), pp 531-547

Arhin, K. "Traditional Rules in Ghana, past and present", 1985.

Arhinful, D. K. (2003) The Solidarity of Self-Interest. Social and Cultural Feasibility of Rural Health Insurance in Ghana.Africa Studies Centre, Research Report 71/2003. Africa Studies Centre, 2300 RB Leiden.

Aulus Cornelius Celsus," De Medicina", (First century AD, Rome)

Birmingham, W., I. Neustadt, and EN. Omaboe, Ed. (1966) A Study of Contemporary Ghana, Vol 1: The Economy of Ghana, London; George Allen and Unwn Ltd.

Boakye Frimpong, Prince (2013) "The Quest for Equity in the Provision of Health Care in Ghana" 2013

Brenya, Edward, Adu-Gyamfi, Samuel. (2014) Interest Groups, Issue Definition and the Politics of Healthcare in Ghana, Public Policy and Administration Research, Vol.4, No.6, 2014,

Chadwick, E. (1842) "The Health of Nations. Extract from the Report of the Poor Law Commissioners on an Inquiry into the Sanitary Conditions of the Labouring Population of Great Britain", London, pp.369-372.

Conger, J. A., \& Kanungo, R. S. (1988). Toward a behavioral theory of charismatic leadership in organizational settings. Academy of Management Review, 12, 637-647.

Conger, J. A., \& Kanungo, R. S. (1998). Charismatic leadership in organizations. Thousand Oaks, CA: Sage.

Devlo, Delanyo (2001). "The Health Sector Reform and Deployment, Training and Motivation of Human Resources towards Equity in Health Care: Issues and Concerns in Ghana", Ministry of Health, the Republic of Ghana.

Ghana Demographic and Health Survey Report. (2008). www.dhsprogram.com.

Ghana Health Service ICT Department www.ghanahealthservice.org

Ghana Statistical Service. (1988a). Ghana Demographic Health Survey (GDHS, 1988). Accra-Ghana: Ghana Statistical Service.

Gillard, Patrick. (2008) Cambridge Advanced Learners Dictionary, A definition of health, Cambridge university press, Third edition.

Gyasi, R.M, Mensah C.M, Ose-wusu Adjei P, and Agyeman, S., (2011), "Public Perceptions of the Role of Traditional Medicine in the Health Care Delivery System in Ghana" 2011

Helen, M. Walker," Contributions of Karl Pearson". Journal of the America Statistical Association, volume. 53, No. 281 (March 1958) 2282561, www.jstor.org. 25 $5^{\text {th }}$ October, 2015.

Konotey-Ahulu, F. I. D., Ocloo, E., Addy, P. M., Bamford, A. M., \&Ennin, C. (1970). Report of the committee appointed to investigate Hospital fees. Accra-Ghana: Ministry of Health

Konotey-Ahulu, F. I. D., Ocloo, E., Addy, P. M., Bamford, A. M., \&Ennin, C. Report of the committee appointed to investigate Hospital fees. Accra-Ghana: Ministry of Health, 1970.

Konotey-Ahulu, F. I. D., Ocloo, E., Addy, P. M., Bamford, A. M., \&Ennin, C. (1970) Report of the committee appointed to investigate Hospital fees. Accra-Ghana: Ministry of Health.

Lioyd F. Novick and Cynthia B. Morrow, (2011) "Defining Public Health: Historical and Contemporary Developments. 
Macmillan English Dictionary, a definition of public health, Holtzbrinck Publishing Group and BC Partners. Second edition.

Mumford, M. D., \& Van Doorn, J. R. (2001). The leadership of pragmatism: Reconsidering Franklin in the age of charisma. Leadership Quarterly, 12, 274-309

Nkrumah K, Towards Colonial Freedom (1962), Heinemann

Nukunya, GK. (2003) "Tradition and Change in Ghana: An Introduction to Sociology". Ghana University Press, Accra.

PRAAD, Kumasi, ARG 1/14/5/7, Kumasi Public Board Ordinance, $10^{\text {th }}$ December 1934

PRAAD, Kumasi, ARG 1/14/5/7, Kumasi Public Board Ordinance, $10^{\text {th }}$ December 1934

PRAAD, Kumasi, ARG 2/14/16, Infectious Diseases return for the week ended, 22 June, 1946

PRAAD, Kumasi, ARG 2/14/16, Infectious diseases return for the week ended, 22 June, 1946

PRAAD, Kumasi, ARG 2/14/2/1, Outbreak of Small Pox in Kumasi

PRAAD, Kumasi, ARG 2/14/60, List of Vaccination Centres in Asante

PRAAD, Kumasi, ARG 6/14/1, Health Week, Kumasi from $24^{\text {th }}-30^{\text {th }}$ November, 1929

PRAAD, Kumasi, ARG 6/14/2 Outbreak of Small pox at Osino and Anyinam

PRAAD, Kumasi, ARG 6/14/2, Regulations made by the Governor in Council under Section 17 of the Diseases of Animals Ordinance, 1936.

PRAAD, Kumasi, ARG 6/14/2, Regulations made by the Governor in Council under Section 17 of the Diseases of Animals Ordinance, 1936.

PRAAD, Kumasi, ARG 6/14/21, Outbreak of small pox at Osino and Anyinam

PRAAD, Kumasi, ARG2/14/29, Outbreak of small pox in Kumasi Prison

PRAAD, Kumasi, ASH, 18b. Improvement on Midwifery after Independence.

Rooney, D., Kwame Nkrumah: vision and tragedy. Legon, Accra, Ghana: Sub-Saharan Publishers, 2007.

SAPRI report April, "Impact of SAP on Availability of and Access to Health Care in Ghana" 2011

Sarpong Peter. (1974) Ghana in Retrospect: Some Aspects of Ghana Culture, Ghana Publishing Corporation, Tema.

Senah, Kojo "In Sickness and in Health: Globalization and Health Care Delivery in Ghana, 2001.

Senah, Kojo. (2001) "In Sickness and in Health" Globalization and Health Care Delivery in Ghana

Simpson W. I., (1909) Sanitary matters in the Various West African Colonies and the Outbreak of plagues in the Gold Coast. London: Crown Agents.

Sir John Pringle, (1752) "Observations on the diseases of the Army: an early science of epidemiology and the prevention of cross infection". Journal of Epidemiology and Community Health, Volume 59, Issue 11, www. Jech.bmj.com

Stedman's Medical Dictionary (1961), A definition of health, Waverly Press, Inc. Baltimore, MD, Twentieth Edition.

Suhrcke M, de Paz Nieves C. (2011) "The impact of health and health behaviours on high-income countries: a review of the evidence". WHO Regional Office for Europe, Copenhagen,

The Case of Health Care Provision", European Scientific Journal, November 2014 edition vol.10, No.33

Twumasi, P. A. (1981) Colonialism and international health: A study in social change in Ghana. Social Science. \& Medicine. Part B: MedicalAnthropology, 15(2), 1981, 147-151. doi:10.1016/0160-7987

Umberto, Gelatti (2015) "Department of Medical and Surgical Specialties, Radiological Science and Public Health" Journal of Public Health Research, Volume 4, No 2.

Water Aid. "National Water Sector Assessment in Ghana" (2008). Www.wateraid.org.

Winslow C.E.A (1920) “The Untilled Fields of Public Health" p.34

World Bank Report on Health, 2012, pp - 17

World Health Organisation, definition of health, (1946) World Health Organization, "African Regional Health Report... The health of the people"

World Health Organization (1946), a definition of public health, www.WHOconstitution.com.

World Health Organization (2000,2002); definition of Traditional Medicine. 